\title{
Technology Education and Economic Competitiveness in Developing Countries: The Sri Lankan Experience
}

\author{
Anthony N. Ezeife, Ph.D. (University of Windsor) \\ T. Arivalagan, (Dharga Nagar National College of Education)
}

\begin{abstract}
This paper examines the status of technology education in developing countries generally, and Sri Lanka in particular. A review of current literature reveals that science and technology are critically important for every country's socio-economic development. The conceptual framework and major features of technology education that should be emphasised in developing countries are discussed. The paper also highlights some severe barriers and limitations that inhibit technology education in developing countries. It is concluded that the Sri Lankan economy requires an effective implementation of appropriate technology education, and that this implementation must begin with scientific and technological literacy at the school level. This holds true for other developing countries currently battling the myriad problems arising from technological deprivation and backwardness. The paper contends that technological education could play the role of enhancing the right kind of technological development and advancement that could over time transform the economic fortunes of, and living conditions in developing countries.
\end{abstract}

\section{Résumé}

Cet article examine la situation de l'enseignement de la technologie dans les pays en voie de développement en général et en Sri Lanka en particulier. Un compte-rendu de la littérature contemporaine révèle que les sciences et la technologie ont une importance indispensable pour le développement socio-économique de tout pays. On y discute le cadre conceptuel et les principales caractéristiques de l'enseignement de la technologie sur lesquels devront insister les pays en voie de développement. L'article met également en relief les barrières et les limitations qui entrave l'enseignement de la technologie dans ces pays. De là, l'article conclut que l'économie du Sri Lanka exige l'exécution efficace d'une formation technologique appropriée et que cet exécution devra commencer par une connaissance scientifique et technologique au niveau scolaire. Cela est aussi vrai pour les autres pays en voie de développement qui sont en train de lutter contre une myriade de problèmes qui proviennent de la privation et du retard technologiques. L'article soutient que la formation technologique pourrait jouer le rôle d'améliorer la forme correcte du développement et du progrès technologiques, qui pourrait dans un certain temps, transformer les fortunes économiques et les conditions de vie dans ces pays en voie de développement. 
Advances in technology greatly affect every aspect of human activity in today's world. Without doubt, every nation has realised that the use of technology has not only come to stay, but also will be required by people to meet the challenges of utilizing technological gadgets and appliances in their day-to-day lives. Technology is driving much of human life with information technology, biotechnology, and other innovations blazing a path of remarkable changes in the manner in which we live, function, and work. Hence, countries need an educated population that will be able to create and use new technological skills and knowledge. Education is the primary source through which students can acquire technological skills and knowledge required to participate in a competitive global economy. Adequate technological education throughout the elementary and secondary school enhances students' success in post-secondary studies and in the workplace. Furthermore, it is through technology education that students would be acquainted with the opportunities provided by various technologies that have relevance to their health and physical well-being.

Science and technology have reached such a unique worldwide status today that no country can afford to treat them with levity. Eggleston (as cited in Ojo, 1996) noted that it is a basic truth that no nation or individual can survive at any level of development without science and technology. Technology constitutes the most significant, and indeed, indispensable tool for the economic development of a nation. Generally, the status and power of a country in the world today depends, to a great extent, on the level of technological development of that country, and the extent to which the country uses technology to find effective solutions to its socioeconomic problems.

Considering current socioeconomic and technological developments, the world has been broadly divided into two parts: developed and developing countries. The living conditions in the poor, developing countries on the one hand, and the developed, industrialized, and usually rich nations on the other hand, differ sharply. Since the developed countries have attained their level of development mainly through the application of science and technology, this study set out to examine how developing countries can achieve rapid development and economic competency through technology education. This is the focal problem that the paper addresses.

In this paper, the term "technology" stands for both a body of knowledge and action. Technology is the knowledge and resources utilized by people in developing, producing, using, and assessing products, structures and systems. It extends the human potential for controlling and modifying the natural and human-made environment (Write, Israel \& Lauda, as cited in Gilberti, 1999). According to the International Technology Education Association (ITEA) "Technology is the modification of the natural environment to satisfy perceived human wants and needs" (as cited in Dugger \& Naik, 2001, p.1). The term "developing countries" is used in the paper to denote all non-industrialized countries. Such countries are found primarily in Africa, Asia, and Latin America (International Encyclopedia of Educational Technology, 1996). 
Technology education allows learners to acquire technological literacy and work skills. In addition, it provides them with the skills to apply scientific knowledge to overcome and solve environmental problems. Technology education is a "study of technology which provides an opportunity for students to learn about the process and knowledge related to technology. It is needed to solve problems and extend human potential” (Dugger \& Naik, 2001, p. 1). As a result of studying technology at the school level, students gain a level of technological literacy. This provides learners the ability to use, manage, assess, and understand technology. Dwelling further on this, Dugger and Naik (2001) noted that technology education is concerned with the broad spectrum of technology. It encompasses a vast area, such as design making, problem solving, technological systems, resources and materials, criteria and constraints, processes, controls, optimization and tradeoffs, inventions, and many other topics dealing with human innovation. This falls in line with Ezeife's (1994) apt summary which stated that technology education can be "looked upon as that aspect of education which not only enables learners to acquire technological literacy and work skills but also provides them with the skills to apply scientific knowledge to the improvement of their environment, solve environmental problems, and strive for the betterment of life in general" (p. 67).

Quite often, technology education is considered the same as technical education when it is seen in a narrow sense. However, technology education is far more complex than technical education. According to Penna (as cited in Ojo, 1996), technical education mainly focuses on the practical knowledge to perform skilled jobs. Its purpose and content are strictly for a specific occupational task and workplace. However, technology education is education for the mastering of the practical, theoretical and ethical knowledge inherent in a technical device or system.

\section{Need for Technology Education}

Governments in developing countries face the task of eradicating disease, poverty, and hunger. They hope their salvation lies in science and technology. Also, they feel that if a large-scale effort is devoted to research in science and technology, this would lead to the fruitful exploration and appropriate use of the natural resources often abundant, but relatively untapped, in many developing countries.

Lewis (2000) asserted that an understanding of technology is vital in the modern world, and it must be part of everyone's basic education. Lack of understanding of technological methods makes people more and more dependent on others in daily life as we progress into the future. To avoid this situation, therefore, there is a need to make technological education an integral part of general education all over the world, especially in areas where the need is most pronounced -- in developing countries. One of the most salient features of the contemporary world is the tremendous transformation science and technology have brought. Drucker, as cited in Vajpeyi and Natarajan (1991),

14 Canadian and International Education Vol. 35 no. 1 - June 2006 
states that, "the scientific anticipation of the probable future and its chief technological aspect are quite indicative of the technologicalization of our time" (p. 1). Continuing, the same author stated that most of the developed Western countries and the less-developed Southern nations have accepted that technological and industrial development are indispensable for economic progress. Thus, technology is seen as a major contributor to the success of any nation's economy. It produces the important workforce, which is the backbone of every country's economy. Walsh stated, "At the level of society there is the issue of supply. It is conceivable that the shortage of skilled trades' personnel will become the critical constraint on economic growth and the maintenance of a competitive edge in productivity and quality” (as cited in May, 1990, p. 8). Symington (1997) emphasizes that there is a relationship between the economic development of a nation and the state of development of science and technology in that nation. Thus, if the school curriculum of a country dwells appropriately on science and technology, then, most likely, the country would become a modern society in which the citizens reap the economic benefits of scientific and technological development.

On an optimistic note, Acquaye (2001) strongly believes that science and technology would help developing countries to improve their living conditions in the near future. Governments in the developing countries have the added duty to catch up with the scientific and technological advancements made in the industrialized countries in all facets of development such as health, agriculture, shelter, communication, transportation, environment, and sports. To be able to catch up, these developing countries need to improve the quality of their science and technology education. Thus, a country like Sri Lanka should vigorously pursue the development of her technological education program to make her economically competitive. This paper sets out to explore the ways and means Sri Lanka and other developing countries would effectively improve the quality of their technology education, which would in turn, enhance the economic competitiveness of these countries.

\section{Situation in Developing Countries General Overview}

In general, developing countries struggle to keep pace with the global economy. The gap between developed and developing countries grows wider by the day. In the area of computer technology, for example, computer-based instruction in developing countries is rare because computers and other technologies are too expensive to acquire and maintain. In addition, since they do not have the expertise in these technologies themselves, they keep lagging behind the developed nations. The other problem that arises with regard to the use of computers in developing countries is that computers require a reliable source of power, persons skilled in installation and maintenance, and a good system of roads and communication to allow access to the technology. Computers cannot run without power. Many schools and establishments in developing countries neither have reliable power supply nor adequate infrastructure to house 
computers. In some cases, high dust and humidity levels constitute hazards to computers (Reeves \& Harmon, 1993). The use of local languages is another factor that limits the use of computer technology in developing countries. Since the medium of instruction in some of these countries at all levels of education is a local language, students are not able to read and apply computer programs written in English or other widely spoken languages. This is true in countries like Indonesia, Malaysia and Thailand. Therefore, the computer programs for the different subjects, which are written in English, have to be translated into the local language to be understood by both trainers and learners. The translation process is tedious, time consuming, and usually overwhelming for the few qualified translators on whose shoulders the task falls. In the area of global trade, developing countries often have trade restrictions with other countries that prohibit importing critically needed new technologies. Additional restrictions imposed by the scarcity of funds further compounds this situation.

In most developing countries, the old educational system did not pay any particular attention to science, technology and engineering. The main purpose of this old educational system was to develop a high degree of literacy within the local community, which served the administrative duty of transmitting messages, keeping accounts, and the ability to function as servants to erstwhile colonial masters. It is obvious that the educational system has not completely provided appropriate learning opportunities for all children and adults in terms of technology education. It is needless to say that appropriate basic technology education is the cornerstone for improving further education, which would lead to the development of new technologies. According to Njah ndam (1997), in general, most developing countries do not have a welldeveloped industrial base to support sustainable industrial growth and socioeconomic development.

\section{Factors Leading to Status Quo: A Historical Perspective}

Today's developing countries were former colonies of Western nations. Some scholars have opined that many of the economic problems currently experienced by developing countries are traceable to their past political and colonial history. For example, the exploitation of resources by former colonial powers left many nations without an economic foundation from which to function. In addition, when the expatriate personnel departed from the country, there were no trained, educated indigenous workers to fill the positions which they vacated. This often led to chaos, revolt and revolution; and the same lack of replacement for personnel in the technical areas often led to regression in the industrial, agricultural, and service sectors, which added to the economic problems of developing countries (Pytlik, 1983).

Ezeife (1994), having studied the immediate post-colonial era in these countries, observed that following the colonial period, the developing nations adopted Western technologies and tried to introduce them directly into their economies without first adapting such technological materials and processes to 
suit local situations. The inadequate preparation of local personnel to operate machinery, the lack of proper maintenance skills, and the lack of adequate infrastructure for the future needs of the technological system largely contributed to the current stunted growth of technology in developing economies. In most cases, the industrialized nations import raw materials for processing from developing countries at very cheap rates, and then send the finished products back to those developing economies at exorbitant prices, a situation which is not helpful in improving the economic situation in these countries. In fact, the living conditions in many of these developing countries are worse now than they were during the colonial period. The reasons for this situation may be numerous, but it is clear that the lack of a sustainable approach to developing technology education has played a major role in the failure of developing countries to progress toward a more dignified standard of living.

Simon (1980) observed that while millions of people from among the educated class in developing countries are unemployed, millions of jobs are waiting to be done because people with the right kind of education, training and skills cannot be found. Moreover, the World Bank Report noted that the formal education system had been "irrelevant to the needs of developing countries for the past two decades" (as cited in Pytlik, 1983, p. 3). The situation is still the same in most developing countries two decades after Pytlik's study (see for example, Ezeife, 2003). It is necessary, therefore, to break this cycle of irrelevance in the educational system. This can be done by laying a strong, sustainable developmental foundation through appropriate, well-funded, and foresighted technology education in developing countries.

\section{The Sri Lankan Experience}

Sri Lanka is an island with an area of 65,610 square kilometres situated in the Indian subcontinent. In the past, the strategic position of the country on the ancient sea routes led to its being colonized by the Portuguese, the Dutch, and finally, the British. The British had complete control over the whole country for nearly 150 years up to1948 when Sri Lanka received her independence. In spite of several educational reforms, the Sri Lankan education system still shows considerable British influence largely in terms of the structure and organization of the educational system.

In addition, Sri Lanka is a multi-racial and multi-religious country. The Singhalese are in the majority, representing $74 \%$; the Tamils constitute $18 \%$, while the Muslims, made up of three main groups, namely, the Sri Lankan Moors, the Indian Moors, and the Malays constitute 7\% of the population. The remaining $1 \%$ of the population comprises the Burghers, the Veddah and other small groups (Federal Research Division, Library of Congress, 2006). In terms of religion, $69 \%$ of the Sri Lankan population is Buddist, with about $15.5 \%$ Hindus, 7.6\% Christians, and 7\% Muslims. The country's economy is based largely on agriculture. The export of tea and rubber still accounts for more than half of the total foreign exchange earnings. 


\section{Education System}

In 1945, prior to the independence of Sri Lanka in 1948, a special committee on educational reforms, known as the Kannankara Committee, proposed to provide free education in the vernacular languages of Singhala and Tamil from Grade 1 to university level. This proposal was implemented in primary schools in 1945, secondary schools in 1953, and universities in 1960. This education policy increased enrolment rates and rapidly boosted the country's literacy level. As a result, Sri Lanka today enjoys an adult literacy rate of $90 \%$.

The country operates a formal education system accountable to the Ministry of Education, Higher Education, and Educational Services. Since 1945, education at all levels has been publicly funded. The General Certificate of Education, Ordinary Level (GCE O/L) examination is held at the end of Grade 10. Based on their performance on this examination, pupils are selected for admission into Advanced Level (GCE A/L) secondary schools. The choice of subjects by students in the senior school is also determined by their results in stipulated subjects on the GCE O/L examination.

Moreover, those who fail to qualify for the secondary school, as well as those who dropped out early, do get a chance to attend various middle-level vocational or technical institutes run by the Ministry of Education and other ministries.

In the field of higher education, there are twelve universities but they can accommodate less than $2 \%$ of qualified students who have completed their higher secondary level examination. Only $1.8 \%$ of students who sit for the GCE $\mathrm{A} / \mathrm{L}$ examination are admitted into the universities. The remaining $98.2 \%$ cannot gain entry into the universities. This is a very low rate of participation in university education. The opportunities in the non- university tertiary sectors, mainly technical and polytechnic education, are limited and the quality of training is poor. According to Medagama (1999), the situation in the nonuniversity tertiary sector, technical and vocational sectors is even worse. Moreover, even the few graduates who obtain university degrees do not find employment in the private sector because these graduates lack English language proficiency and technical skills.

\section{Science and Technology in Schools}

In 1998, Sri Lanka embarked on a major reform of formal education from primary to university. In the reformed system, science is introduced as introductory science in Grades 4 and 5, while science and technology are introduced at the secondary level. Hence, at the GCE O/L, students are given the opportunity to select an optional technical subject. Sri Lanka has been facing many problems in implementing science and technology at the secondary school level. The country's poor physical infrastructure is the main barrier to proper teaching of science and technology in schools. Lack of communication facilities, non-availability of potable water and an inadequate electricity supply are the main barriers which create problems in school education. Jayatilleke (1999) has 
noted that there has been no compulsion to conduct practical classes at all levels in science and technology teaching in schools over the past four decades. The laboratory equipment in many schools is usually not in good working condition. Shortages in production and printing of textbooks, supplementary reading materials, absence of regular teacher training and upgrading programs, and shortages of qualified science teachers are some of the issues that inhibit the effective teaching of science and technology in schools.

In addition to all of these factors, lack of English language proficiency is also a barrier. In Sri Lanka, over the past four decades, formal education is conducted in the national language, which is not English. However, a few science courses are taught in English at the university level but students who take these courses often do not possess adequate English proficiency to enable them to perform well in the courses. At present, under the new education reform, action has been taken to improve the teaching of English at the primary and secondary levels of education. Hopefully this reform will improve performance in science and technology courses at the higher levels.

During the past two decades, Sri Lanka has been adversely affected by internal ethnic conflicts. This is one of the main hurdles in the nation's development. The Sri Lankan government was compelled to commit large amounts of resources to the war and so did not have any reserves for developmental purposes, including technological development.

\section{Technology Education in Sri Lanka}

Technology education has been a part of school curriculum for a long time in the Sri Lankan education system. However, before 1972 it was seen as a subordinate subject. The earliest technology education was started during the British colonial period (1798-1948); and in those days, it was called "handicraft". Agriculture, woodwork, needlework, fiber work, and home economics were taught. Even though the above subjects were part of the school curriculum, the teaching of the subjects at the school level faced many difficulties, mainly, lack of qualified teachers, inadequate equipment, insufficient financial support, minimal teaching hours, and out-of-date curricula (Dayasena, 1976).

In 1972, the Sri Lankan government introduced an educational reform which gave a prominent role to vocational subjects at the secondary level. However, that reform was implemented only up to 1977 because the new government which came to power in 1977, did not continue with the reform. The evolution of technology education in Sri Lanka progressed from handicrafts to vocational education, then to technical or technological education.

Due to the major educational reform of 1998, technical subjects were included as core or compulsory subjects. Agriculture, gardening, animal husbandry, marine biology, resource technology, food science technology, home economics, electronic and electrical technology, and mechanical technology are reference subjects which students have to select at the secondary level (i.e., Grades 10 and 11). At the higher secondary levels (i.e., Grades 12 and 13), the 1998 education reform introduced eight technology subjects. These subjects 
include civil technology, electrical and electronic technology, mechanical technology, food technology, bio-resource technology, soft material technology, and service-related technology. The treatment of each subject is not expected to be exhaustive, rather, it is supposed to be context-based, and arranged so that concepts and principles will be presented in a comprehensive manner. Topical issues will be focused on as points of entry. As stipulated in the reforms, laboratories and workspaces would be provided to introduce pupils to instrumentation, creation of technological information, and elements of design (Jayatilleke, 1999).

Beyond the secondary level, the formal technical education in Sri Lanka is offered in three tiers, with degree-level engineering courses at the top, diploma-level technical courses at the middle, and the certificate-level craft courses at the bottom. Degree-level engineering courses are offered at the Sri Lankan Universities at Peradeniya and Moratuwa. The middle-level diploma certificate courses are offered by technical colleges and the certificate craft courses by vocational training institutes.

Currently, a total of 25 technical and seven affiliated technical units exist in the island and they offer a total of 66 courses, which have been classified into three broad areas, namely, craft and engineering studies, business studies, and general studies. The courses vary in duration from three months to a year, and are offered either on a full-time or part-time basis, while the certificates are classified as national diploma, national certificate, or short courses.

The recent educational reform has generated a considerable interest in Technical Education and Vocational Training (TEVT) in Sri Lanka. In 1998, the institutions responsible for TEVT were brought under the umbrella of one Ministry called the Ministry of Vocational Training and Rural Industries (MVTRI). The MTVRI maintains the following institutions:

Tertiary and Vocational Education Commission (TVEC).

Department of Technical Education and Training (DTET).

Vocational Training Authority of Sri Lanka (VTA).

National Institute of Technical Education (NITE).

The TVEC is a statutory body responsible for policy formulation, coordination, and planning and development of technical education and vocational training. In Sri Lanka, the DTET, with a 106-year history, delivers a formal type of technical education in technical colleges and affiliated institutions located in major provincial and district capitals. The VTA, as a statutory body, provides training programs under the Labour Department to serve the rural, unemployed youth through employment-oriented, short courses at Rural Vocational Training Centres. 


\section{Figure 1}

Reforms in Sri Lankan National Education System, 1998

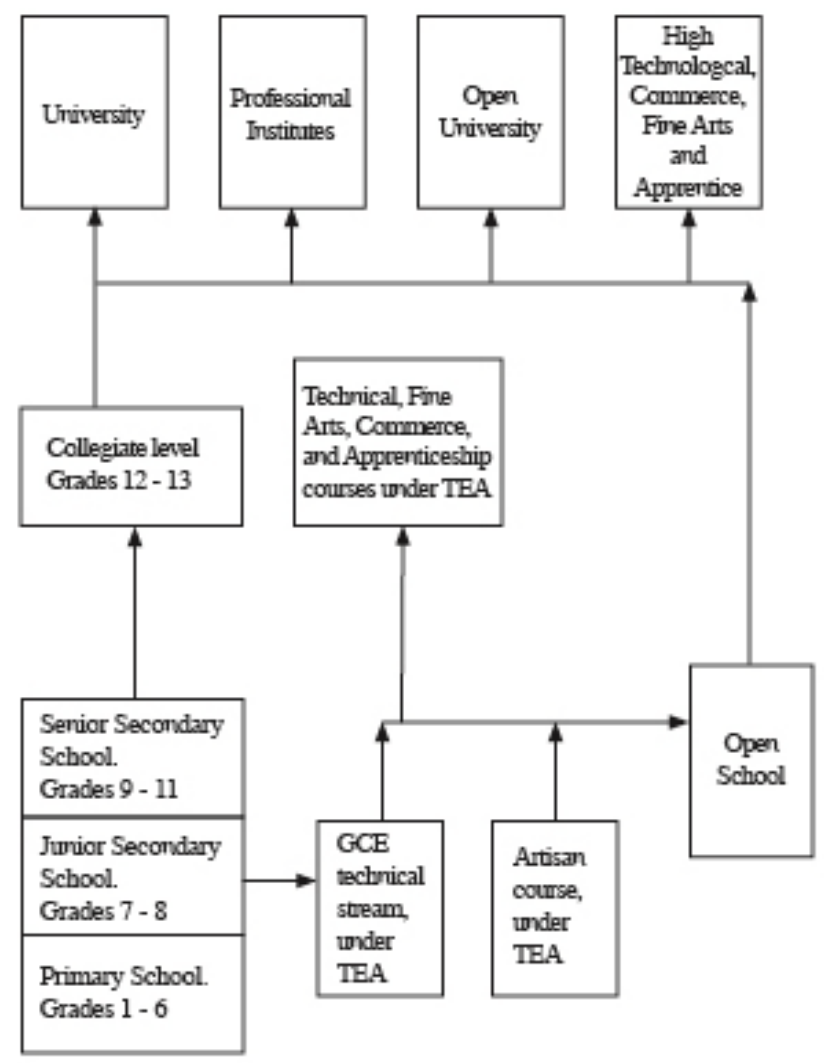

Education canadienne et internationale Vol. 35 n ${ }^{0}$ 1- Juin 200621 
Finally, NITE is responsible for the training of trainers and development of curricula, training methodology, and teaching materials for technical education (NITE, 1998). These new reforms, as articulated in The Encyclopedia of Comparative Education and National System of Education (1998) are shown diagrammatically in Figure 1.

Note that in Figure 1, each starting point leads to a definite, meaningful concluding point, which is beneficial to the recipient. Thus, all levels of education, starting from the primary school, are included in the reformed technological education plan. The numbers $10^{+}, 13^{+}$, and so on, indicate the age ranges of the students, while TEA stands for Technical Education Authority.

\section{The Path to the Future \\ Past and Current Barriers/Problems}

If past efforts in the development and sustenance of appropriate technology education in several developing countries have not been quite successful, the obvious questions to ask would be: Why did these efforts fail, and what can be done to prevent a repeat of past mistakes and shortcomings as plans are made for the future? This section will address these crucial questions. According to Ogunniyi (2000), the significant contribution made by various international organizations towards the development of science and technology in developing countries in the last three decades has resulted in both success and failure. A small amount of success has been achieved in African nations in the development of skilled science and technology personnel, an increase in student enrollment in school science and technology courses, development of new curricula and instructional materials, formulation of new policies, expansion of teaching and learning facilities, and the in- service training for teachers. On the other hand, failure would include mass failure in public examinations, inadequate facilities to keep pace with student enrollment, high teacher-pupil ratios in classrooms, high dropout rates, lack of skilled science and technology personnel including trained teachers, conflicting policies, and poor networking within countries. Moreover, the poor economic conditions in most African countries promote school drop-out rate and "brain drain" and have worsened the countries' personnel development. The "brain drain" on the intellectual capital of African countries has been a major problem in the past two decades.

Lafort, (as cited in Ogunniyi, 2000), observed that between 50,000 and 100,000 top scientists and researchers, engineers, technicians, and doctors have migrated from the developing countries every year to the industrialized countries. This adversely affects the developing countries in terms of economic and personnel development. For example, in Nigeria in the mid-1970s, one of the departments at the University of Ibadan had over 30 academic and support staff. However, within a decade, the number had decreased by half. After two decades, the same department was less than a third of what it was in the mid 1970s and the remaining staff members were seeking work abroad. 
Further, the quality of science and technology education has worsened over the past two decades in some African nations. The quality of educational products has also faced setbacks. The diplomas awarded in some developing countries are no longer accepted as meeting the admission requirements for higher studies in industrialized countries. Another pertinent issue is the fragile, at times volatile, political situations in many developing countries. If there is political instability, then education cannot flourish, and technology education in particular is most adversely affected because potential international partners and experts with the wherewithal to establish a viable technological system would not be willing to venture into unsafe zones. National politics is also a factor to consider because in developing countries politics is very much tied to education and plays a significant role in national policies and decision-making. Therefore, educators would generally not propose or accept any new educational programs that would not be perceived as politically attractive by the leaders in their countries. Thus, if the leaders are uninformed or lukewarm about the need for technology education, then educators are unable to make any meaningful progress without political support and approval, for example, in matters of funding and site allocation for technological endeavours.

Further, Williams (1991) argued that technology education in terms of the general education offered in developing countries would not constitute a solid base for the students who will later pursue vocational training. This is because the general education curriculum lacks adequate vocationally oriented content, especially at the early levels. The industries that do exist do not offer on-the-job training and cannot accommodate young people who want to learn technical skills. The high school graduates, as well as drop-outs, have to create employment for themselves.

\section{Tackling Identified Problems; How to Move Forward}

The path to the future of technology education in developing countries has to be paved and controlled by experiences gathered from past mistakes. Lewis (2000) argues for the option of introducing technology into the curriculum of developing countries in a way that is appropriate to the circumstances under which teaching will take place. In some developing countries, some students often do not get beyond the primary level of education. Thus, if at the primary school level they were not exposed to technological education, then they would leave school without being aware of the immense benefits of technology in the modern world. Consequently, modern technology-based tools and applications would largely remain alien to them. Therefore, serious consideration has to be given in these countries to the inclusion of technology education at the primary school level. The Sri Lankan model given in Figure 1 is appropriate for technology education in developing countries because it aims at integrating technology into all levels of education from primary school to the university level. Technology as reconstituted industrial art is probably the most viable option for developing countries either at the primary or secondary levels. Often, 
in developing countries, how technology is taught and learned is influenced by external examination syllabuses that may not be relevant to local circumstances.

Teaching technology appropriately in developing countries would require greater consideration of local everyday industries such as fishing, weaving, shelter, and transportation, amongst others. The key to success here lies not in the sophistication of the facilities and equipment but in how useful and relevant technological education is to local economies. People in the community who have the relevant expertise can come together to shape the curriculum and to help implement it. Knowledgeable people from industry, the universities, and elsewhere in a community can collaborate with specialist teachers in designing the curriculum and in working with students as they try to find and solve community problems. In general, the development and sustenance of appropriate technology education in developing countries across the globe have to be tied to the overall relevance of educational experiences of learners, and to the local or native background knowledge they bring to the learning situation. As Taylor (2004) aptly observed, the community a child lives in shapes and influences her/his consequent learning outcomes.

For maximum effect, technology can be taught across the curriculum. This will imply integrating technology into the curriculum of other subjects rather than being taught as a single subject. It can be correlated with agricultural science, home economics, art, science, and a host of other subject areas at both the elementary and secondary levels. For instance, agricultural science as a school subject has great potential as a vehicle for teaching technology in developing countries. Agriculture has been a fundamental part of rural existence, and has a viable potential for carrying out technological innovations within the program of agricultural studies. Students can be taught how to use fertilizers, how to practise crop rotation, irrigation, and so on. Solar, wind, sea wave, and biogas energy applications can be taught in technology areas such as grain drying, local electricity-generating devices, water-pumping and other irrigation machines. Students can be assigned to community projects where they can work collaboratively with engineers, farmers, and local craftspeople. In this way, students can gain valuable experience while addressing real technological problems associated with agricultural production in the local setting. Home economics is another subject in the school curriculum that could potentially provide many opportunities for technology education in developing economies. In home economics, students have a chance to experience the application of technology to the betterment of human existence. For example, food preservation and food preparation are two main areas wherein technological innovation would be particularly beneficial, especially in rural areas. Students could be taught to explore technologies related to drying, canning, and fermenting. Solar power and biogas techniques could be utilized in the construction of simple stoves for cooking. Preparation and preservation technology could be effectively tapped in rural areas where surplus fruits, vegetables, grains and other food items are produced. There could be 
commercial possibilities for these food products, thereby enhancing the economic competitiveness of developing countries.

Of all subject areas, science might be considered the most suitable for the introduction of technology into the primary, as well as secondary curriculum. The challenge would be to find situations in everyday life that provide opportunities to show the connection between science and technology. As Ezeife (2003) noted, the focus in developing countries should be to make science and technology education not just environmentally sensitive and application-oriented but also integrated with the day-to-day life of learners. For instance, principles of physics can be shown to underlie the functioning of flashlights that are commonly used during the frequent power outages in many developing countries. Electron flow can be taught in connection with simple electric circuits used in wiring during outdoor ceremonies. Principles of electricity, thermodynamics, and mechanics can be explored through practical technological applications such as simple machines like pulleys and inclined planes frequently used in weight lifting, truck loading, electric motors, and bicycles commonly utilized for transportation in many developing economies.

\section{Conclusion}

The challenge facing developing countries, including Sri Lanka, is the urgent need to use their resources to establish and effectively implement functional and sustainable technology education. To meet this need, these countries have to develop the capacity to assimilate, adapt, and create technology. If they intend to participate competitively in the world economy, developing countries have to focus on acquiring an indigenous base and capability in science and technology rather than attempting to import technological expertise directly from developed nations. Imported technology can only go so far; homegrown technology has the potential to go much farther. For example, if tractors are to replace oxen in developing farming economies, then there must be competent local mechanics who can repair the tractors when they break down. The need for technological education, and the use of technology in education, can no longer be ignored. As Spence and Haughey (2005, p. 93) aptly summarized, interest in this area "is growing which would indicate a good beginning, but steps are needed if the gains made are not to be wasted." There is no doubt that modest gains have been made in the field of technological education in developing countries, but a rigorous effort has to be made to consolidate, sustain, and further build on these gains. The Sri Lankan model of technology education (see Figure 1) that aims at integrating technology into the teaching curriculum at all levels of education is an example worthy of emulation and full-scale implementation. 


\section{References}

Acquaye, H. A. B. (2001). Science education in developing countries. Science Education Journal, 85(1), 68-72.

Dayasena, W. (1976). Pre-vocational education in Sri Lanka. Paris: The UNESCO Press.

Dugger, W. E., \& Naik, N. (2001). Clarifying misconceptions between technology education and educational technology. The Technology Teacher Journal, 61 (1), 31-35.

Ezeife, A . N. (1994). Technological education and economic competitiveness in developing countries: A case study of Nigeria. The Journal of Education and Economic Change, 67-76.

Ezeife, A. N. (2003). Using the environment in mathematics and science teaching: An African and aboriginal perspective. International Review of Education, 49(3-4), 319-342.

Federal Research Division, Library of Congress. (2006). Sri Lanka: Country Studies. Retrieved March 30, 2006 from http://rs6.loc.gov/frd/cs/lktoc.html

Gilberti, A. F. (1999). Why technology should be integrated into the curriculum as a core subject. Retrieved January 28, 2004, from http://vnweb.hwilsonweb.com/hww/results/results single.jhtml?nn=14

International Encyclopedia of Educational Technology (2nd ed.). (1996). Cambridge, UK: Cambridge University Press.

Jayatilleke, C. L. V. (1999). Sri Lanka. Retrieved February 1, 2005, from http://www.ibe.unesco.org/national/chanapdf/llSriLanka.pdt

Lewis, T. (2000). Technology education and developing countries. International Journal of Technology and Design Education, 10, 163-179.

May, L. (1990). Science and technology advising youth: Curriculum development and implementation. Unpublished master's thesis, University of Windsor, Windsor, Ontario, Canada.

Medagama, R. S. (1999). Perspectives in education in the next decade. Retrieved May 10, 2006, from http://www.preal.cl/FIE/pdf/lopbc/Arunatilake.pdf

National Institute of Technical Education of Sri Lanka (NITE) (1998). Objectives and major activities of the Institute. Retrieved April 28, 2006, from http://www.sdp.slt.lk/national_institute.html

Njah ndam, S. (1997). The need for industrial human resources development in developing countries. (Eric Document Reproduction Service No. ED445263)

Ogunniyi, M. B. (2000). Unitwin/UNESCO chairs program and capacity building in science and technology in Southern Africa. Science Education, 84, 401-417.

Ojo, D. A. (1996). Barriers to functional and qualitative technology education in developing countries: Nigeria as a case study. (Eric Document Reproduction Service No. ED392626)

Pytlik, C. E. (1983). The role of technology education in third world development. (Eric Document Reproduction Service No. ED230813)

Reeves, T. C., \& Harmon, S. W. (1993). Computer-based instruction in developing countries. Educational Technology Journal, 33(9), 32-35.

Simon, J. (1980). The education dilemma. New York: Pergamon Press.

Spence, M. A., \& Haughey, M. (2005). Issues and challenges of instructional technology specialists in Alberta colleges. Canadian Journal of Learning and Technology, 31(1), 79-97.

Symington, D. (1997). Science, technology, and economic development: An issue for schools? Australian Science Teachers’ Journal, 43(3), 7-11.

26 Canadian and International Education Vol. 35 no. 1 - June 2006 
Taylor, P. J. (2004). Fruits of democratic transformation of education in a South African university in 1998: Perspectives of students in the School of Education, University of Cape Town. McGill Journal of Education, 39(3), 283-303.

The Encyclopedia of Comparative Education and National System of Education (1st ed.). (1998). Headington Hill Hall, Oxford, England: Pergamon Press.

Vajpeyi, D., \& Natarajan, R. (Eds.). (1991). Technology and development: Public policy and managerial issues. New Delhi: Kaveri Publishers.

Williams, P. J. (1991). Technology education as a general education in developing countries. Journal of Cooperative Education, 26(3), 73-75.

World Education Encyclopedia (1st ed.). (1985). New York: Facts on File Publication.

Teacher Educator, Anthony N. Ezeife, is a Professor of Mathematics and Science Education in the Faculty of Education, University of Windsor. A muchtravelled educator, Dr. Ezeife has taught, and done extensive cross-cultural research in several countries across the globe. His main research focus is on the improvement of science, technology, and mathematics (STM) education in traditional and indigenous settings world-wide, and the use of STM for the improvement of living and economic conditions in developing countries.

T. Arivalagan is a Lecturer at Dharga Nagar National College of Education, Dharga Nagar, Sri Lanka. His research focuses on science and technology education, and the improvement of teacher training curricula using modern technological approaches and resources 